\title{
Aplastic crisis and transient neurological symptoms due to parvovirus B19 infection in a patient with chronic hemolytic disorder
}

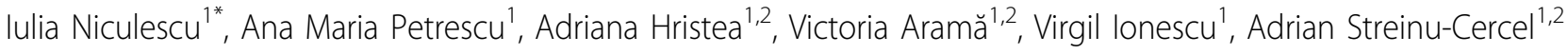 \\ From The 9th Edition of the Scientific Days of the National Institute for Infectious Diseases Prof Dr Matei \\ Bals \\ Bucharest, Romania. 23-25 October 2013
}

\section{Background}

Human parvovirus B19 is considered an important trigger of aplastic crisis in patients with chronic congenital hemolytic disorders.

\section{Case report}

We describe the case of a young adult known with hereditary microspherocytosis who presented with fever, marked agitation and confusion and a slight left hemiparesis. The cerebral imaging revealed multiple giant cystic VirchowRobin spaces, but no other abnormalities. The complete blood counts showed pancytopenia and the peripheral blood smear revealed reticulocytopenia, confirming the diagnosis of aplastic crisis. Human parvovirus B19 infection was proven by the detection of serum DNA using PCR technique. After the initiation of packed red cells transfusion a favorable outcome was seen and his neurologic symptoms fully remitted.

\section{Conclusion}

Direct invasion of human parvovirus B19 may induce both aplastic crisis and acute encephalopathy in patients with hereditary spherocytosis. Human parvovirus B19 may induce aplastic crisis but also acute encephalopathy through direct invasion, although in our case the transient neurological symptoms were rather an effect of hypoxia.

\section{Authors' details}

${ }^{1}$ National Institute for Infectious Diseases "Prof. Dr. Matei Bals", Bucharest, Romania. ${ }^{2}$ Carol Davila University of Medicine and Pharmacy, Bucharest, Romania.

\footnotetext{
* Correspondence: iulianiculescu81@gmail.com

${ }^{1}$ National Institute for Infectious Diseases "Prof. Dr. Matei Balş", Bucharest, Romania

Full list of author information is available at the end of the article
}

Published: 16 December 2013

doi:10.1186/1471-2334-13-S1-P87

Cite this article as: Niculescu et al:: Aplastic crisis and transient neurological symptoms due to parvovirus B19 infection in a patient with chronic hemolytic disorder. BMC Infectious Diseases 2013 13(Suppl 1):P87.

\section{Submit your next manuscript to BioMed Central and take full advantage of: \\ - Convenient online submission \\ - Thorough peer review \\ - No space constraints or color figure charges \\ - Immediate publication on acceptance \\ - Inclusion in PubMed, CAS, Scopus and Google Scholar \\ - Research which is freely available for redistribution \\ Submit your manuscript at www.biomedcentral.com/submit}

C Biomed Central

(C) 2013 Niculescu et al; licensee BioMed Central Ltd. This is an Open Access article distributed under the terms of the Creative Commons Attribution License (http://creativecommons.org/licenses/by/2.0), which permits unrestricted use, distribution, and reproduction in any medium, provided the original work is properly cited. 